DOI: $10.19195 / 0137-1150.167 .18$

\author{
NATALIA KAŹMIERCZAK
}

Uniwersytet im. Adama Mickiewicza w Poznaniu, Polska

\title{
Как умирает другой. Художественная антропология смерти в творчестве Вацлава Серошевского (на материале произведений На краю лесов и Предел скорби)
}

В настоящее время наблюдается постепенное вытеснение осмысления смерти из социальной и культурной сферы. Исключение переживания смерти из сознательной жизни человека ведет к потере осмысленности человеческого бытия в целом. енной предельности и ведет к потере осмысленности человеческого бытия в целом ${ }^{1}$. Поэтому ценными являются обращения к наследию писателей, предпринявших попытку творческого освоения феномена смерти.

В научно-критических работах, посвященных „сибирским произведениям” Вацлава Серошевского, с особенным усилием подчеркивается гуманизм ${ }^{2}$ и своеобразная этнографичность ${ }^{3}$, выраженная, прежде всего, в стремлении писателя к наибольшей точности в отражении подробностей жизни якутского населения. Литературный анализ творчества В. Серошевского направлен главным образом на попытки прочтения интересующих нас текстов сквозь призму биографии польского писателя и сосредоточены на указании особенностей своеобразного натурализма в способе художественного отражения окружающего мира ${ }^{4}$. Богатство символического пласта произведения, до-

1 Ж. Бодрийяр, Символический обмен и смерть, пер. С. Н. Зенкина, Москва 2000, с. 231.

${ }^{2}$ К. Такасаева, Труды Ваилава Серошевского как основа конструирования якутской этничности в условиях иивилизационного пограничья, „Debaty IBI AL” т. IV, 2011, c. 144.

${ }^{3}$ См.: A. Kijak, Odkrywca innej Syberii i Dalekiego Wschodu. O prozie Wacława Sieroszewskiego, Kraków 2010; E. Orzeszkowa, Gwiazda wschodzi, „Tygodnik Ilustrowany” 1898, № 6, с. 102; № 7, c. 129-132; № 8, c. 149-153; A. Potocki, Najmłodsi powieściopisarze polscy, „Tygodnik Ilustrowany” 1899, № 27, c. 525, № 28, c. 545-548.

4 A. Kijak, Odkrywca innej Syberii..., c. 141-147.

Slavica Wratislaviensia 167, 2018

(C) for this edition by CNS 
стигаемое благодаря осознанной ассимиляции конкретных этнографических деталей и фольклорных мотивов, выходит, как правило, за пределы намеченных исследовательских переспектив.

Заглавие настоящей статьи преднамеренно отсылает к работе Иоганеса Фабиана Как умирают другие: размышления об антропологии смер$m u^{5}$. Ученый высказывает знаменательную мысль о потребности изучения феномена смерти в широком антропологическом контексте, включающем как трансцендентальную перспективу проблемы, так и ее универсальное измерение ${ }^{6}$. Приближение мировоззрения Другого требует обязательного учета полюса субъективности, поскольку без обращения к собственному опыту и эмоциям преодоление границы взаимопониания я и „экзотического" Другого невозможно 7 . С другой стороны, в современных попытках концептуализации понятия „Другой” отчетливо выделяется вытекающая из стремления к синтезу идей диалогизма мысль, что подлинное осмысление явлений бытия возможно только в коммуникативном существовании с другим, не-я ${ }^{8}$.

Преодоление разрыва между Я и Другой, достигаемое благодаря выявлению общего значения явления смерти в частных его проялениях, открывается в художественной антропологии Вацлава Серошевского. Экзотические элементы и приемы архаизации быта Другого, довольно подробно описанные в научной литературе ${ }^{9}$, использовались писателем с целью конструкции такой точки зрения повествования, которая в наибольшей мере послужит приближению образа иной культуры. В избранных для данного анализа произведениях наблюдаются различные повествовательные конструкции: в повести На краю лесов (1896) повествователь близок главному герою - события и их оценка переданы с точки зрения молодого представителя европейской интеллигенции, в свою очередь в повести Предел скорби (1900) сюжет реализуется с позиции объективированного повествователя, с одной стороны, создающего определенную дистанцию взгляда на происходящее, с другой, избегающего оценочной перспективы указываемых событий. Попытка сопоставления художественных образов, воспринимаемых сквозь указанные призмы повествовательной структуры, должна указать на смысловое содержание „экзотики” Другого в более широкой перспективе.

${ }^{5}$ И. Фабиан, Как умирают другие: размышления об антропологии смерти, пер. О. Трефиловой, „Археология русской смерти” 2016, № 2, с. 204-231.

6 Там же, с. 209.

${ }^{7}$ На необходимость соучастия и понимания Другого сквозь призму собственных переживаний указывал также Ренато Росальди, см.: Р. Росальди, Скорбь и гнев охотников за головами, пер. А. Евтягина и С. Мохова, „Археология русской смерти” № 2, 2016, с. 179.

${ }^{8}$ Новейший философский словарь, сост. А. А. Грицанов, Минск 2003, с. 342.

${ }^{9}$ A. Kijak, Odkrywca innej Syberii..., c. 141-147. 
Последовательно воплощаемая писателем стратегия построения литературного образа человека позволяет рассматривать этот образ на нескольких (хотя и взаимопроникающих, но, однако, поддающихся смысловой дифференциации) конструкционных уровнях: 1. уровень телесного (внешность, природа), вещественного (бытовые детали, предметы); 2. уровень духовного $^{10}$ (нравственные ценности) и психологического (сознание, подсознательное, эмоции, память). Подчеркнем, что важнейшее место в художественном отражении психических процессов занимают именно телесновещественные детали.

Упомянутый телесно-вещественный уровень (черты внешности, окружающая природа, предметы быта) выстраивается писателем при помощи характерных для данного этноса социокультурных образов и культурная выразительность Другого сохраняется и подчеркивается именно на этом уровне произведения. Принципы художественного отображения бытовых подробностей жизни северного народа, создающие „этнографический” слой произведений подчинены главным образом смыслообразующей функции. То есть специфика этнографического пласта повести заключается в установлении смыслового потенциала бытовой детали путем указания ее в контексте избранных явлений культуры. Следовательно, художественное осмысление быта не только воспроизводит повседневность, но и эстетизирует ее, то есть писатель творчески осваивает обыденную реальность этноса, чтобы приблизиться к сущности познаваемых явлений.

Среди эстетически значимых элементов вещественного заметно выделяются образы приготовления пищи. Архетип приготовления еды, связанный с женским началом, отсылает к пониманию этого действия в космогоническом смысле. Семантически содержательной деталью для интерпретации повести является факт потребления продуктов, приготовляемых из молока. Топленое масло дает силу и исцеляет недуги: „Хотя жажда их мучила страшно, но, исполняя заветы старины, они не пили чаю, а только теплое, топленое масло, «дающее свежесть груди и упругость усталым членам»"11.

Мотив молока ассоциируется с материнством и заботой, шире - рождением, истоком. Молоко - „эликсир жизни” 12 - наполняется также дополнительной семантикой - оно становится всепроникающей и объединяющей основой. Заложенный в рассматриваемых текстах смысловой потенциал этого мотива является одним из факторов, непосредственно указывающих

${ }^{10}$ С. В. Козлов, разделяет три уровня возможного анализа художественного образа человека, см.: С. В. Козлов, Литературная антропология и поэтика персонажа, „Филологические науки. Вопросы теории и практики” 2013, № 7, с. 93.

11 В. Л. Серошевский, На краю лесов, [в:] его же, Якутские рассказы. Рассказы, повести, воспоминания, Москва 1997, с. 134. Все дальнейшие ссылки на это издание даются в тексте с указанием названия произведения и номера страницы в скобках.

12 Г. П. Козубовская, Рубеж XIX-XX веков: миф и мифопоэтика, Барнаул 2011, с. 73. 
не только на влияние русской культуры на культуру северных народов, но и своеобразный синтез этих культур в мировоззрении якутов. Прокаженные $^{13}$ [Предел скорби] устраивают праздник по случаю масленицы - праздника молока ${ }^{14}$. В последовательности праздничной трапезы и наступившего после нее голода прослеживается параллель художественного пространства с реальным: согласно православной традиции - масленица предшествует Великому посту. Символика молока, таким образом, восходит к сфере празднично-сакрального смыслового пространства. Молоко в этом произведении также образно связано с землей. Корову, выкармливающую прокаженных, можно понимать как олицетворение Матери-Земли ${ }^{15}$. При этом для осуществления художественной модели дихотомического синтеза, организующей смысловые уровни текста и моделирующей его структуру, образ этого животного наделяется двойственной семантикой. Корова-кормилица во время пожара загораживает своим телом выход из юрты, а потом разрушает ее, лишая жителей возможности спастись.

Богатство смыслового содержания, отсылающего к универсальным мифологическим корням, содержит образ огня, воплощающего одновременно и разрушительную стихию, и обеспечивающую поддержание жизни силу, мужское начало ${ }^{16}$. „Когда я дом строил, не думал, что останется он пустым, что потухнет огонь мой... ", - сожалеет о минувшем Грегорей [Предел скорби, с. 259]. Чуть тлеющий или угасающий очаг сопутствует угасанию жизни.

Павел схватил старика за руку: она была вялая; приложил ко рту ухо - он уже не дышал. Раздул Павел поспешно чуть тлеющий огонь и опять наклонился над стариком. Мертвые, погасшие зрачки сурово на него взглянули, сердце не билось, а изо рта сочилась тонкая струйка уже стынувшей крови [На краю лесов, с. 234].

Очаг, занимающий центральное место в юрте, образует сакральное пространство, с которым связаны разнообразные ритуальные запреты. Грегорей не позволяет бросить отвалившиеся пальцы Салбана в огонь, Течение не желает сжечь зараженную рыбу - осквернение огня вызывает гнев божества — „огонь не любит скверноты, сердится, мстит”, — говорит Течение [Предел скорби, с. 276]. Огню приносят жертву и просят о покровительстве.

Почтенный рыжебородый Старик, Господин Наш Огонь - очаг! Покровитель скота! Воспитатель и защита детей наших... Прими ласковым сердцем нашу убогую

13 В. Л. Серошевский, Предел скорби, [в:] его же, Якутские рассказы. Рассказы, повести, воспоминания, Москва 1997, с. 259. Все дальнейшие ссылки на это издание даются в тексте с указанием названия произведения и номера страницы в скобках.

14 Л. В. Борисова, Базисные архетипы и стереотипь национальной культуры в языковой картине мира, „Вестник Челябинского государственного университета” 2013, № 16, c. 22 .

15 Д. Тресиддер, Словарь символов, Москва 1999, http://slovo.yaxy.ru/67.html [дата обращения: 24.11.2016].

${ }^{16}$ К. М. Королев, Энциклопедия символов, знаков, эмблем, Мидгард 2005, с. 396-397. 
чистосердечную жертву и в будущем не оставь нас милостью своей, дари, посылай нам скот многий и пестрый, мохнатых жеребят, мальчиков тугопальцых, способных натягивать лук, и румяных девушек с молочными грудями... - молилась Анка, бросая в огонь куски жирной рыбы [Предел скорби, с. 263].

Представление об огне как очищающей и излечивающей силе показано в главе, посвященной путешествию Анки к князю [Предел скорби, с. 295]. Якуты разводят огонь перед прокаженными и собою, и только после этого начинается беседа. Выжигание места, где стояла юрта прокаженных, должно остановить и уничтожить смертельный недуг.

Символическим содержанием насыщен также акт потребления пищи. Как констатирует Ольга Фрейденберг, „еда, — центральный акт в жизни общества - осмысляется космогонически; в акте еды космос (тотем, общество) исчезает и появляется. [...] Тотемический характер такой еды сказывается в том, что акт разрывания и разгрызания представляется актом бессмертия, слияния человека и тотема, человека и космоса"17. Образное отражение связи еды и смерти отчетливо выражено в сцене свежевания оленя:

Между тем Андрей проворно отрезал голени животного, повернул тушу вверх животом, подложил с обоих ее боков по толстому бревну и, раньше чем Павел сообразил, в чем дело, сделал продольный разрез вдоль «белой линии» и стал свежевать оленя. Как только края обвисли настолько, что можно было за них ухватиться, дети и женщины принялись помогать, кто руками, а кто даже зубами. Довольные рожи, вымазанные кровью и жиром, когтевидные руки, рвущие мясо, белые крупные зубы, теребящие влажную свежую кожу — во всей этой картине было что-то беспощадное, волчье, каннибальское, что заставило Павла неприятно вздрогнуть [На краю лесов, с. 135].

В повести Предел скорби прокаженные устраивают „пиршество” из остатков своих запасов. Вследствие особого художественного отражения одного из важнейших элементов повседневного принятие пищи прочитывается как метафорическое воплощение постоянного кругового перехода от уничтожения-поедания-разрывания еды к восстановлению-рождению и снова к смерти. Разрывание рыбы переходит в разрывание мертвого полугнилого тела Салбана, которое Мергень выносит на съедение волкам. В оригинальном варианте повести (на польском языке) Мергень съедает своего ребенка ${ }^{18}$. Ее тело, как и тела Анки, Грегорея и Течения, погибших в пожаре, съедает медведь. Так конституируемый образ потребления пищи, разрывания и поглощения, сотнесенный с постоянным превращением раздробленного в целое, целого в раздельное и снова в целое, и живого в мертвое, и мертвого в живое, актуализирует мифологическое представление о мироздании.

Мотивы цикличности мироздания и смерти как перевоплощения, связанные также с символикой растительного мира, являются центральными

17 Цит. по: Г. П. Козубовская, Рубеж XIX-XX веков..., с. 72.

18 В авторском переводе повести на русский язык указанный фрагмент отсутсвует. Ребенок Мергень погибает от голода. Cp.: W. Sieroszewski, Bokser. Kulisi. Dno nędzy, Warszawa 1948, с. 30-64 и В. Л. Серошевский, Предел скорби..., с. 245-319. 
в сюжете якутских народных сказок, цитируемых в рассматриваемых текстах В. Серошевского. В сказке о „низенькой старушке с пятью коровами” [Предел скорби, с. 256] старушка находит в широком поле цветок, который превращается в прекрасную девушку. Девушке суждено погибнуть от руки соперницы и вновь стать цветком, который найдет низенькая старушка 19 . Сказочный образ девушки, сошедшей с Верхнего мира и погибающей и воскресающей в виде растения, близок мифологическому образу умирающего и воскресающего божества ${ }^{20}$. Образ растения объединяет в себе значения вечного возобновления и угасания жизненных процессов. Мифологические корни сюжета цикличного перехода от хаотического к созидательному (девушка становится родоночальницей якутов) прочитываем не как образное осмысление природных явлений, а как своеобразное „энергетическое напряжение на грани бытия" 21.

В сказке о человеке по прозвищу Бер-Хара [На краю лесов, с. 209], смерть персонажа также сменяется возрождением в образе растения. Универсальный характер мифологического материала обосновывает поиск в использованных Серошевским сказочных сюжетах следов космогонических мифов. Ценную интерпретацию этих мифов находим в работе Михаила Евзлина Космогония и ритуал:

В закрытом (структурированном) мире, отделенном от своего энергетического источника (бездны) происходит истощение питающих его энергий. Поэтому для поддержания его существования становится необходимым нисхождение бога в подземный мир, в котором он соприкасается с бездной, наполняется ее энергиями и возрождается, и вместе с ним возрождается все мироздание, которое через бога восполняет свои истощенные энергии. В этом состоит онтологическое содержание ритуала, повторяющего драму миротворения ${ }^{22}$.

Обращение к мифологической цикличности бытия и восстанавление архетипического содержания воздействует на эмоциональный уровно воспринимающего сознания и создает необходимые эстетические условия вовлеченности в происходящее. Следовательно, цикличность, восстаналивающая связь с утраченным прошлым и выстраивающая его заново в настоящем, не только упорядочивает время, но и обеспечивает своеобразное единство группы во времени и пространстве.

Художественная антропология писателя находит свое выражение также на аксиологическом уровне восприятия текста. Смерть Другого в рассматриваемых произведениях мыслится и как завершающий момент бытия живого создания, освобождение от страданий, и как универсально значимый феномен, преодолевающий границы культурных различий. Наиболее показательным художественным освоением феномена смерти в этом кон-

\footnotetext{
19 Якутские народные сказки, сост. В. В. Илларионов, Новосибирск 2008, с. 195-218.

${ }^{20}$ Н. В. Емельянов, Народные сказки якутов, [в:] Якутские народные сказки..., с. 49.

${ }^{21}$ М. Евзлин, Космогония и ритуал, Москва 1993, с. 100.

22 Там же.
} 
тексте считаем конституирование противоборства полярных ценностей, приближающегося к трагическому конфликту ${ }^{23}$ в повести Предел скорби. Фиксируемые в тексте черты трагического связаны прежде всего с женскими персонажами - именно женское воплощает дихотомическое взаимодействие созидающего и разрушающего начал. Динамика действия зиждится на конфронтации влюбленных в одного мужчину женщин - кроткой Анки и страстной Мергень. Безграничное чувство, руководящее действиями героинь, и предельная пассивность Грегорея (объекта любви) возносят „любовный конфликт” до уровня неразрешимой трагической коллизии. Болезнь, изолирующая жителей небольшого селения от внешнего мира, не касается названных женщин, благодаря чему в конструкции конфликта осуществляется своеобразная модель свободы выбора. Мергень не в силах вынести потерю любимого и решается на его и Анки убийство, но, осознав совершенное, бросается в пылающую юрту.

Катарсическое воздействие финальных сцен повести осуществляется на „пепелище” ценностей, а также благодаря своеобразной изоляции героев, выстраивающей своеобразную перспективу „взгляда со стороны”. Вследствие переживаемого сострадания, финальная мысль о вечности душевной и физической боли сопряжена с чувством примирения с так устроенным миропорядком. Конституируемая кольцевой композицией цикличность художественного времени реализует идею вечно повторяющихся космических перевоплощений.

Подводя некоторые итоги, можно констатировать, что художественное восприятие феномена смерти Серошевским зиждется прежде всего на понимании специфики мировоззрений северного этноса как результат взаимодействия природы и человека ${ }^{24}$. То есть в авторской концептосфере отношение человека к смерти вытекает из диалогической совокупности культурного и природного. Поэтому реинтерпретация произведения Серошевского в спектре современной литературной антропологии, как можно предполагать, откроет возможность перцепции имманентной направленности текста на художественное осмысление ценности культурного потенциала Другого.

\section{Библиография}

Бодрийяр Ж., Символический обмен и смерть, пер. С. Н. Зенкина, Москва 2000.

Борисова Л. В., Базисные архетипь и стереотипь национальной культуры в языковой картине мира, „Вестник Челябинского государственного университета” 2013, № 16.

23 В традиционном понимании этой эстетической категории, см.: M. Janion, Romantyzm. Rewolucja. Marksizm, Gdańsk 1972, c. 13-34.

24 Согласно концепции космо-психо-логоса Георгия Гачева, см.: Г. Гачев, Национальные образы мира, Москва 1988. 
Гачев Г., Национальные образы мира, Москва 1988.

Евзлин М., Космогония и ритуал, Москва 1993.

Козлов С. В., Литераткрная антропология и поэтика персонажа, „Филологические науки.

Вопросы теории и практики” 2013, № 7.

Козубовская Г. П., Рубеж XIX-XX веков: миф и мифопоэтика, Барнаул 2011.

Королев К. М., Энщиклопедия символов, знаков, эмблем, Мидгард 2005.

Новейший философский словарь, сост. А. А. Грицанов, Минск 2003.

Серошевский В. Л., Якутские рассказы. Рассказы, повести, воспоминания, Москва 1997.

Росальди Р., Скорбь и гнев охотников за головами, пер. А. Евтягина и С. Мохова, „Археология русской смерти" 2016, № 2.

Такасаева К., Труды Ваилава Серочевского как основа конструирования якутской этничности в условиях циивилизационного пограничья, „Debaty IBI AL” т. IV, 2011.

Тресиддер Д., Словарь символов, Москва 1999, http://slovo.yaxy.ru/67.html.

Фабиан И., Как умирают другие: размышления об антропологии смерти, пер. О. Трефиловой, „Археология русской смерти” № 2, 2016.

Якутские народные сказки, сост. В. В. Илларионов, Новосибирск 2008.

Janion M., Romantyzm. Rewolucja. Marksizm, Gdańsk 1972.

Kijak A., Odkrywca innej Syberii i Dalekiego Wschodu. O prozie Wacława Sieroszewskiego, Kraków 2010.

Orzeszkowa E., Gwiazda wschodzi, „Tygodnik Ilustrowany” 1898, № 6, 7, 8.

Potocki A., Najmłodsi powieściopisarze polscy, „Tygodnik Ilustrowany” 1899, № 27-28.

Sieroszewski W., Bokser. Kulisi. Dno nędzy, Warszawa 1948.

\section{How the Other dies: The artistic anthropology of death in Vaclav Seroshevsky's works (based on the works: At the Edge of the Woods, The Depths of Misery)}

\section{Summary}

The paper focuses on the comparative analysis of Vaclav Seroshevsky's novels At the Edge of the Woods and The Depths of Misery in the context of the anthropology of death. The author concentrates on the specificity of the perception of death by a particular ethnic group. The reinterpretation of the writer's works shows the model of the intended symbolization of the depicted world through the creative assimilation of ethnographic elements.

Keywords: ethnic group, the Other, anthropology of death 


\section{Jak umiera Inny? Artystyczna antropologia śmierci w twórczości Wacława Sieroszewskiego (na podstawie utworów Na kresach lasów, Dno nędzy)}

Streszczenie

Artykuł poświęcony jest analizie porównawczej powieści Wacława Sieroszewskiego Na kresach lasów i Dno nędzy w kontekście antropologii śmierci. Rozważania autorki opracowania koncentrują się na wyjawieniu specyfiki percepcji śmierci przez określoną grupę etniczną. Próba ponownego odczytania tekstów pisarza pokazuje model świadomej symbolizacji świata przedstawionego poprzez twórczą asymilację elementów etnograficznych.

Stowa kluczowe: grupa etniczna, Inny, antropologia śmierci 